\title{
Analysis of Constraints of Rural Beef Cattle Cooperative Farmers: A Case Study of Ga-kibi, Norma and Mogalakwena in Blouberg
}

\author{
Isaac Azikiwe Agholor ${ }^{1}$ \\ ${ }^{1}$ Department of Agricultural Economics, Extension and Rural Development, University of fort Hare, South Africa \\ Correspondence: Isaac Azikiwe Agholor, Department of Agricultural Economics, Extension and Rural \\ Development, University of fort Hare, South Africa. E-mail: isaaco477@yahoo.com
}

Received: April 22, 2013 Accepted: June 15, 2013 Online Published: July 15, 2013

doi:10.5539/jas.v5n8p76 URL: http://dx.doi.org/10.5539/jas.v5n8p76

\begin{abstract}
Agricultural co-operatives are tools used to accelerate the process of agricultural development. Co-operatives in South Africa are useful tools used to assuage poverty and improve the living standard of the rural household through pooling together the available resources. There is emerging evidence that beef cooperatives and their members can benefit from market oriented agriculture when smallholders farmers are integrated into the value chain management. Furthermore, institutional provisions along the value chain and policies seldom prioritize the needs of smallholder farmers and thus increased the barriers to production and market access. The purpose of this study is to evaluate production and marketing constraints as perceived by beef cattle cooperative farmers in Ga-kibi, Norma, and Mogalakwena. The specific objectives of the study were: (i) to assess production and marketing constraints of beef farmers' cooperative; and (ii) to determine the role of speculators (traders) in marketing of beef cattle. The paper succinctly examines the tottering problems of speculators and concomitant contribution in the marketing of beef animals in the study areas. The study adduces some reasons for the poor performance of beef co-operatives in achieving their goal. These include amongst others: problem of pest and diseases, water stress, inadequate marketing infrastructures, insufficient market access, price fixing of culled stocks, labour and stock pilfering. Logistic regression was used to evaluate perception of constraints by beef cooperative farmers'. The response pattern revealed that the ability of farmers to perceive constraints increases with number of years of farming experience. The study concludes with proposals to improve the performance of agricultural co-operatives in the study areas.
\end{abstract}

Keywords: beef co-operatives, speculators, infrastructures, income source, constraints

\section{Introduction}

\subsection{Background of the Study Area}

Governments of developing countries have often recognized the use of Farmers' Cooperatives to enhance the performance of small-scale farmers. Since 1994, the new democratic government in South Africa has been supporting the growth of cooperatives, especially among historically deprived South Africans, as a strategy to assuage poverty (Tukuta, 2011). The new Cooperatives Act (No. 14 of 2005) under which a variety of cooperatives emerged, was signed into law in August 2005. This Act recognizes that a sovereign and self-sustaining cooperative undertaking can play a major role in the economic and social improvement of small scale farmers (Government Gazette, 2005). However, the new Act emphasised traditional cooperatives where a group of people pull their resources together to satisfy common economic and social needs. According to Philip (2003), cooperatives have significant prospect in contributing towards poverty reduction, enhancing enablement empowerment and generating employment. However, several factors have hindered the performance of smallholder cooperatives in South Africa. A study conducted by Machethe (1990) on poor-performing and failed cooperatives in the former homelands of South Africa asserted that co-operators had no sufficient insight with respect to the purpose, responsibilities and management. Van der Walt's (2005) in his study on "cooperative failures in Limpopo province observed that poor supervision, lack of training, conflict among members and inadequate funds were identified as important causative factors. Similar studies by Kherallah and Kirsten, (2002) emphasised access to start-up capital; knowledge and training in business administration, marketing and bookkeeping; low-levels of education and assertiveness towards work as the causes of non-performance of cooperatives. In many developing countries, including South Africa cattle industry is one of the largest farming 
enterprises. Beef farming has a low input arrangement in terms of costs, labour, time, asset and it contributes to rural livelihood. The cooperative approach to beef production was aimed at enhancing the sales and procurement of inputs, with added benefit of improving the bargaining power of beef cattle farmers in the area, particularly in relation to market prices. In addition, the idea was to reduce the influence of the speculators (traders) on prices of livestock. The availability of formal marketing arrangements is essential for real marketing of livestock. These arrangements comprise of marketing agents, marketing information and value-adding activities within the reach of the producers. However, these measures are missing in most cases especially for rural livestock producers (NDA, 1998); resulting in the restriction of marketing opportunities for smallholder farmers. According to (Bienabe et al., 2004) smallholder farmers in rural areas, have little market information epitomized by level of literacy. In most instances, information is gathered through interaction with other actors in the commodity chain, but the accuracy of this information is not guaranteed, since those actors might be displaying "opportunistic behavour" (Bienabe et al., 2004). Farmers often sell their livestock at prices that are below the market price because of lack of knowledge of local, regional and national prevailing prices. It is therefore, imperative to assess cooperative farmers' constraints in the three villages (Ga-kibi, Norma, \& Mogalakwena) of BLM.

\subsection{Purpose and Objectives}

The purpose of this study is to evaluate production constraints as perceived by beef cattle cooperative farmers in Blouberg Local Municipality. The specific objectives of the study were:

(i) To assess production and marketing constraints of beef farmers' cooperative;

(ii) To determine the role of speculators (traders) in marketing of beef cattle.

\section{Materials and Method}

\subsection{Description of the Study Area}

The study took place in Blouberg Local Municipality (BLM) area which is located in the far northern part of the Capricorn district. Aganang surrounds Blouberg on the South, Molemole on the South West, Makhado on the North East, Lephalale on the North West, Mogalakwena on the Southwest and Musina on the North. The Blouberg Local Municipal area covers an area of approximately $5054 \mathrm{~km}^{2}$ from Polokwane (Appendix 1). The BLM area are inhabited by Northern Sotho (Pedi tribe) with an estimated population of 194 119. (Statistics, South Africa 2007). There are 14 clusters (community groupings) within Blouberg Local Municipality but only three (Ga-Kibi, Mogalakwena, \& Norma) were identified for the study (Appendix 1). The Blouberg local Municipality receives an annual precipitation of about 380 and $550 \mathrm{~mm}$, which falls mostly during summer months (December-January) with average annual temperature of $14-20^{\circ} \mathrm{C}$. The Blouberg Local Municipality (BLM) has also a mixture of sweet and sour grass in some parts of the area but mainly, the area is covered with sweet veld. The grasses that are most common are annual grasses that quickly disappear in winter thereby leaving the ground bare (Zwane, 2006).

\subsection{Sample and Sampling Procedure}

Total of 89 beef cooperative farmers consisting of male and females that were involved in livestock production on sustenance and commercial purposes in Blouberg Local Municipality were purposely selected for this study. In sum, 47 samples of respondents were taken from Ga-kibi, 17 from Norma and 25 from Mogalakwena. A well-structured questionnaire to assess the production and marketing constraints, and the role of speculators in marketing of beef cattle in the study areas was designed in August, 2012. After a pre survey test on beef cooperative farmers and speculators, the questionnaire was modified with the inclusion of few questions.

\subsection{The Approach}

A co-operative is an independent association of persons integrated willingly to meet their common economic, social and cultural needs through a jointly owned enterprise operated on co-operative principles. Speculators are branded traders noted by having access to land and pastures which enable them buy animals at low prices and convert these animals into market-ready animals for resale. A well-structured questionnaire to assess the production and marketing constraints, and the role of speculators in marketing of beef cattle in the study areas was designed in August, 2012. After a pre survey test on beef cooperative farmers and speculators, the questionnaire was modified with the inclusion of few questions. Respondents were interviewed using English and/or Sepedi for farmers who could not speak English. A focus group discussion was also held with the cooperatives farmers. The scheduled focus group meeting was facilitated by the Extension officer attached to the Department of Agriculture in Blouberg Local Municipality. The meeting for the focus group discussion was pre-arranged to coincide with the beef cooperative farmers' normal meeting day. However, prior to the focus group discussion veld drive was carried out with the selected farmers to identify the available production and 
marketing resources in these areas. The speculators/traders were interviewed telephonically on a pre-arranged date and time to elicit information from them on price fixing procedure. The respondents' demographic information, farm characteristics, beef cattle production and marketing constraints, and the role of speculators in marketing of culled beef cattle were recorded. For each question, the proportion of farmers who gave the same responses was calculated for each village and the percentages calculated based on the total number of farmers who responded to each question. Cooperative farmers who failed to respond to certain question were sponged in the analysis. The data collected was reviewed for errors and were pre-set, entered into Microsoft Excel 2010 spread sheet for analysis. The data were analysed using SPSS and statistical Analysis System (SAS) 2003.

\section{Results and Discussion}

\subsection{Demographic Characteristics of Farmers' in the Ga-kibi, Norma and Mogalakwena}

The summary of the demographic data provided in Table 1 portrays that $67 \%$ (Ga-kibi), $24.1 \%$ (Norma) and $31 \%$ (Mogalakwena) of the beef cooperative farmers were males. In contrast female membership of beef cooperatives stood at 34\% Ga-kibi, 9.7\% Norma and 22.6\% Mogalakwena respectively. The ages between 51-60 years, that is $62.5 \%$ for Ga-kibi $16.7 \%$ Norma and $20.8 \%$ for Mogalakwena were involved with beef cooperative (Table 1). The result also shows that the ages between 30- 40years are less inclined to joining farmer's cooperatives as illustrated in Table 1. Overall, respondents in the three areas (Ga-kibi 62.5\%, Norma 12.5\% and Mogalakwena 25\%) had no formal education, while 50\% in Ga-kibi, $14.3 \%$ in Norma and $35.7 \%$ of the beef cooperative had high school education. However, the respondents that had primary education (Table 1) were $58.8 \%$ in Ga-kibi, $23.5 \%$ in Norma and $66.7 \%$ in Mogalakwena.

Table 1. Descriptive statistics for demographic characteristics of farmers in the study areas

\begin{tabular}{|c|c|c|c|c|}
\hline & \multicolumn{3}{|c|}{ VILLAGES } \\
\hline & & $\begin{array}{c}\text { Gaki-bi } \\
(\mathrm{N}=47) \%\end{array}$ & $\begin{array}{c}\text { Norma } \\
(\mathrm{N}=17) \%\end{array}$ & $\begin{array}{c}\text { Mogalakwena } \\
(\mathbf{N}=\mathbf{2 5}) \%\end{array}$ \\
\hline \multirow{2}{*}{ Gender } & Male & 67.7 & 24.1 & 31.0 \\
\hline & Female & 37.3 & 9.7 & 22.6 \\
\hline \multirow{5}{*}{ Age } & $<30$ years & 40.0 & 20.0 & 40.0 \\
\hline & $30-40$ & 50.0 & 20.0 & 30.0 \\
\hline & $41-50$ & 36.8 & 21.1 & 42.1 \\
\hline & $51-60$ & 62.5 & 16.7 & 20.8 \\
\hline & $>61$ & 42.9 & 28.6 & 28.6 \\
\hline \multirow{5}{*}{ Education } & No school & 62.5 & 12.5 & 25.0 \\
\hline & Primary school & 58.8 & 23.5 & 66.7 \\
\hline & Junior school & 50.0 & 16.7 & 33.3 \\
\hline & High school & 50.0 & 14.3 & 35.7 \\
\hline & Tertiary & .0 & 33.3 & 17.6 \\
\hline \multirow{5}{*}{ Farm experience } & $<5$ years & 40.0 & 20.0 & 40.0 \\
\hline & 6- 10 & 33.3 & 33.3 & 33.3 \\
\hline & $11-15$ & 33.3 & 33.3 & 33.3 \\
\hline & $16-20$ & 68.2 & 9.1 & 22.7 \\
\hline & $>21$ & 50.0 & 20.0 & 30.0 \\
\hline \multirow{2}{*}{$\begin{array}{l}\text { Who is involved in } \\
\text { farming }\end{array}$} & Myself & 63.9 & 33.1 & 40.3 \\
\hline & Relation/employee & 36.2 & 8.4 & 17.6 \\
\hline
\end{tabular}

In Ga-kibi village $68.2 \%$ of the respondents interviewed had 16 to 20 years' beef cattle rearing experience; while in Norma and Mogalakwena the situation is different with $9.1 \%$ and $22.7 \%$ respectively. Nevertheless, $40 \%$ in Ga-kibi, $20 \%$ in Norma and $40 \%$ in Mogalakwena had less than 5 years of beef cattle rearing experience. On the whole, majority of the respondents undertake farming activities as a means of livelihood although a small number of them are pensioners who derive extra income from monthly pension. However, there is a substantial variation in the variable: who is actually involved in beef cattle farming? The result revealed that $63.9 \%$ of respondents in Ga-kibi, 33.1\% and $40.3 \%$ in both Norma and Mogalakwena were actively involved in farming respectively (Table 1). Overall, the respondents in Ga-kibi, Norma and Mogalakwena seldom use hired labour with exception of few farmers that are either too old or physically challenged. The result shows that $36.2 \%$ of the 
respondents in Ga-kibi, 8.4\% in Norma and 17.6\% in Mogalakwena implore and use the services of relations or hired labour.

\subsection{Farmers Perception of Production and Marketing Constraints}

The variables used to assess beef farmers' perception of production and marketing constraints were: pest and diseases, water stress, market infrastructure, market access, price fixing, labour and livestock theft.

\subsubsection{Pest and Diseases}

The prevalence of pest and diseases constitute a major constraint to cattle production exacerbated by poor production practices. Almost all farmers in Ga-kibi, Norma and Mogalakwena seldom apply initial control measures but usually adopt treatment procedures when cattle are infected. Overall, $50 \%$ of beef cooperative farmers in Ga-kibi, $20 \%$ in Norma and $50 \%$ in Mogalakwena asserted that pest and diseases limits the production of livestock in the area (Figure 1). According to the respondents, high mortality of their beef cattle is induced by the incidence of tick resulting in the occurrence of Heart water disease.

Table 2. Logistics regression showing years of farm experience and perception of pest and diseases as constraints

\begin{tabular}{cccccccc}
\hline \multicolumn{7}{c}{ Variables in the Equation: } \\
\hline Step 1 $^{\mathrm{a}}$ & Fexp & B & S.E. & Wald & df & Sig. & $\operatorname{Exp(B)}$ \\
& Fexp(1) & 1.317 & .895 & 2.166 & 1 & .141 & 3.733 \\
& Fexp(2) & .480 & .734 & .427 & 1 & .514 & 1.615 \\
& Constant & -.847 & .690 & 1.508 & 1 & .220 & .429 \\
\multicolumn{6}{c}{ Variable(s) entered on step 1: Fexp=Years of farm experience. } \\
\hline
\end{tabular}

The results showed that farmers with farm experience of more than 20 years are 2.62 (1/.381) times more likely to perceive pest and diseases as a constraint as compared to farmers with less farm experience (Table 2). Also, farmers with farm experience ranging from 11-20 yrs are 0.94 times more likely to perceive pest and diseases as a constraint than farmers with less than 11 years farm experience. Therefore, farmers' assessment of constraint increases with number of years of farming experience.

\subsubsection{Water Stress}

The availability of adequate water throughout the year for livestock in the Ga-kibi, Norma and Mogalakwena has been a serious concern for the beef cooperative farmers. Most farmers rely on harvested rain water to cushion water shortages. The sources of water for livestock are bore hole (well), streams or rivers which are in most cases far from the grazing camps. Few of the available boreholes located in the grazing camps are either manually or electrically operated. In Ga-kibi, $50 \%$ of the beef cooperative farmers agreed that water stress constitute a serious constraint in their livestock enterprise while $28 \%$ and $50 \%$ of the respondents in Norma and Mogalakwena respectively also concurred that the problem of water remains unabated in the area. The results of the logistics regression (Table 3) revealed that farmers with farm experience of more than 20 years are 1.78 (1/.563) times more likely to perceive water stress as a constraint than farmers with farm experience of less than 10 years. The findings revealed that the ability of farmers to perceive water stress as a constraint increases with number of years of farming experience.

Table 3. Logistics regression showing years of farm experience and perception of water stress as a constraint

\begin{tabular}{cccccccc}
\hline \multicolumn{7}{c}{ Variables in the Equation } \\
\hline Step 1 & & B & S.E. & Wald & df & Sig. & $\operatorname{Exp(B)}$ \\
& fexp & & & .600 & 2 & .741 & \\
& fexp(1) & -.074 & .846 & .008 & 1 & .930 & .929 \\
& fexp(2) & -.575 & .993 & .336 & 1 & .562 & .563 \\
& Constant & 1.386 & .791 & 3.075 & 1 & .080 & 4.000
\end{tabular}

a. Variable(s) entered on step 1: fexp=Years of farm experience. 


\subsubsection{Market Infrastructures}

The Comprehensive Agricultural Support Programme (CASP) has been mandated to build infrastructures like erection of fences, auction sales pens and ramps for loading and off-loading livestock (NDA, 1998). In the study areas, it is fascinating to note from the focus group discussion that the beef cooperative farmers improvised some infrastructures using indigenous knowledge. In Norma area for example, a group of farmers excavated and manually operated wells (local bore hole) to serve as source of water for their livestock. Marketing infrastructures like feedlots, abattoirs, auction sales pens and ramps are unavailable in the area. Result reveals that in Ga-kibi $68 \%$, Norma $11 \%$ and Mogalakwena $21 \%$ of the respondents agreed that market infrastructure is a major barrier in beef cattle sales. In Ga-Kibi, the beef cooperative farmers asserted that the unsettled impasse between the Local Authority and the Limpopo Department of Agriculture (LDA) has negatively affected the successful completion and commissioning of the feedlot in the area. In Mogalakwena for instance, the situation is different; there are three pumping machines donated by the LDA, but these machines are not utilized because of perennial water problem. The source of water available for livestock in the area is either dried up or inadequate in volume to allow submersible pumping machine to function. Conversely, the beef cooperative farmers in Norma posited that in 2010 the Department of agriculture (LDA) installed submersible water pumps for the existing bore hole in Norma area but it became defective after six months of operation.

Table 4. Logistics regression showing years of farm experience and perception of market infrastructure ras a constraint

\begin{tabular}{cccccccc}
\hline \multicolumn{7}{c}{ Variables in the Equation } \\
\hline Step 1 $^{\mathrm{a}}$ & Fexp & B & S.E. & Wald & df & Sig. & $\operatorname{Exp(B)}$ \\
& Fexp(1) & -.014 & .740 & .000 & 1 & .984 & .986 \\
& Fexp(2) & -.693 & .886 & .611 & 1 & .434 & .500 \\
& Constant & .847 & .690 & 1.508 & 1 & .220 & 2.333 \\
& a. Variable(s) entered on step 1: Fexp= Years of farm experience. \\
\multicolumn{7}{c}{}
\end{tabular}

The perception of market infrastructures as a constraints by beef cooperative farmers was investigated (Table 4) and the result revealed that beef cooperative farmers with longer years of experience (20 years or more) are 2.00 (1/.500) times more likely to perceive market infrastructures as a constraint than farmers with less farm experience.

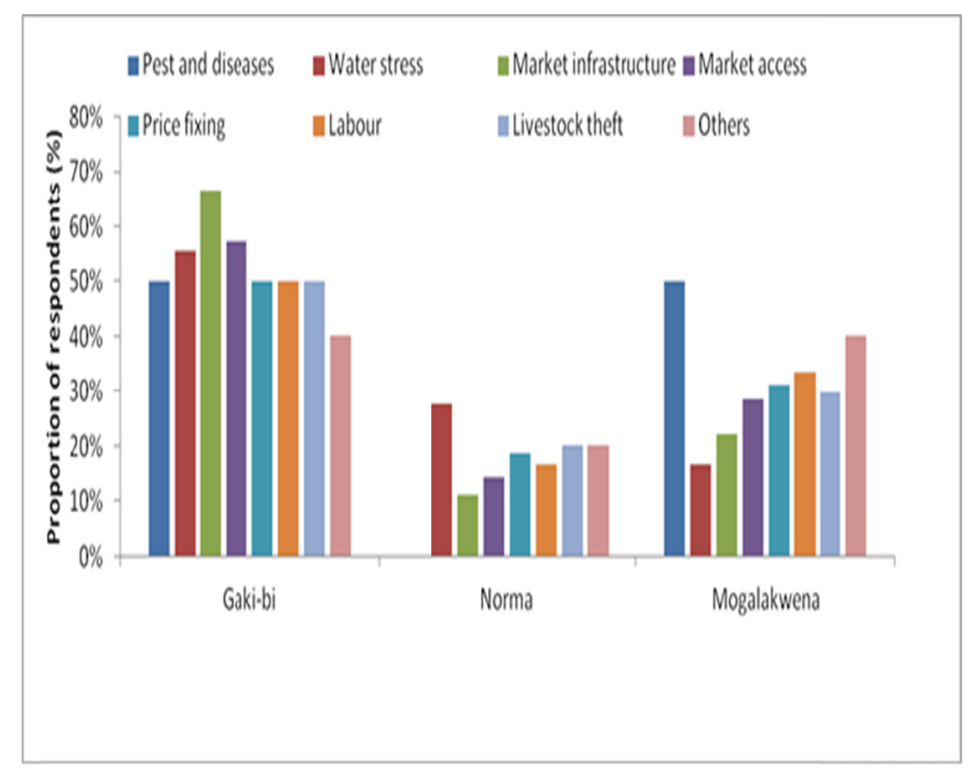

Figure 1. Farmer's perception of production and marketing constraints 


\subsubsection{Market Access}

In South Africa, there are presently five approved networks for sales and marketing of livestock. The approved networks are abattoirs, market agents (speculators), feedlots, butcheries and private sales (NDA, 1998). The beef cattle industry has grown from a controlled environment to one that is completely deregulated today. Numerous policies, such as differences between organised and unorganised areas; payment of levies by producers; regulations on the building of abattoirs; auctioning of animals according to grade and weight was a common feature in the beef cattle industry prior to deregulation of agricultural market. Subsequently, with the deregulation of the agricultural marketing, the prices of beef cattle are settled by the forces of demand and supply. The inclusion of the smallholder farmers in the value chain management is essential for the survival of rural agricultural production and marketing (Van Tilburg, 2012). Since the deregulation of the agricultural market, smallholder farmers have persistently been marginalised in the value chain. Liberalization and deregulation of agricultural markets posed restraints that debar smallholder farmers' market access for agricultural products. In this study however, there was no significant difference in the perception of market access as a constraint in the three villages. In Ga-kibi 56\% (Figure 1) of the respondent were of the view that access to market has been a major hindrance in the sales of their culled beef cattle. In Norma $17 \%$ of the respondents agreed that access to market remains their concern while in Mogalakwena, 27\% (Figure 1) also asserted that inadequate access to the market is an obstacle to the sale of beef cattle despite the existence of cooperatives. According to Makhura and Mokoena (2003) institutional provision along the value chain seldom prioritize the needs and aspirations of the smallholder farmers who are already marginalised and thus increased the barriers to accessing markets. The beef cooperative farmers' access to market in the area was identified as a major problem. However, farmers with farm experience of 20 years and above were $4.00(1 / .250)$ times more likely to consider market access as a constraint than farmers with less farm experience (Table 5).

Table 5. Logistics regression showing years of farm experience and perception of market access as a constraint

\begin{tabular}{lccccccc}
\hline \multicolumn{7}{c}{ Variables in the Equation: } \\
\hline Step 1 ${ }^{\mathrm{a}}$ & Fexp & B & S.E. & Wald & df & Sig. & $\operatorname{Exp(B)}$ \\
& & & 2.509 & 2 & .285 & \\
& fexp(1) & -.351 & 1.113 & .100 & 1 & .752 & .704 \\
& fexp(2) & -1.386 & 1.213 & 1.305 & 1 & .253 & .250 \\
& Constant & 2.197 & 1.054 & 4.345 & 1 & .037 & 9.000 \\
\multicolumn{6}{l}{ a. Variable(s) entered on step 1: fexp= Years of farm experience. } \\
\hline
\end{tabular}

\subsubsection{Price Fixing}

Considering the parameters used for livestock quality and price estimation, beef cooperative farmers are seldom unable to attract reasonable prices for their beef animals in the formal market. Beef cattle are graded as class ' $\mathrm{C}$ ' if it has reached the matured age which implies that such beef cattle will fetch the farmer the lowest price per kilogramme. Too fat or lean beef cattle are not also desirable by potential buyers or speculators. Poor management practices coupled with ill-health also accounts for low prices of beef animals (NDA, 2008). Overall, $50 \%$ of beef cooperative farmers' in Gaki-bi asserted that price fixing by the speculators was a major problem militating against beef production (Figure 1). In Norma, 20\% were of the view that price fixing by speculators poses a major problem while $30 \%$ of respondents in Mogalakwena had similar perception. However, majority of the respondents in Ga-kibi, Norma and Mogalakwena asserted that the concept of grading by speculators before price fixing is not very clear. The grading of beef cattle by speculators for ease of determining the price has also placed farmers in a disadvantaged position. The result revealed that in the three areas, farmers criticized the grading methods used in determining the prices of their beef cattle. This lack of transparency in estimating prices often leads to suspicion and most beef cooperative farmers consider this phenomenon as exploitative. 
Table 6. Logistics regression showing years of farm experience and perception of price fixing as a constraint

\begin{tabular}{|c|c|c|c|c|c|c|c|}
\hline \multicolumn{8}{|c|}{ Variables in the Equation } \\
\hline & & B & S.E. & Wald & $\mathrm{Df}$ & Sig. & $\operatorname{Exp}(B)$ \\
\hline \multirow[t]{4}{*}{ Step $1^{\mathrm{a}}$} & Fexp & & & .251 & 2 & .882 & \\
\hline & $f \exp (1)$ & -.085 & .739 & .013 & 1 & .908 & .918 \\
\hline & $f \exp (2)$ & -.377 & .895 & .178 & 1 & .673 & .686 \\
\hline & Constant & .847 & .690 & 1.508 & 1 & .220 & 2.333 \\
\hline
\end{tabular}

The results showed that farmers with more than 20years farm experience are $1.46(1 / .686)$ times more likely to perceive price fixing as a constraint than farmers with less than 10yrs farm experience (Table 6).

\subsubsection{Labour}

Labour is readily available in Ga-kibi, Norma and Mogalakwena villages. Results revealed that $50 \%$ of the respondents in Ga-kibi use direct labour involving families and relations. In Norma, 19\% of the respondents agreed that labour was not a major constraint while in Mogalakwena 31\% (Figure 1) also agreed that labour does pose a constraint. Overall, beef cooperative member involves members in sharing their normal routine duties. For instance adhoc committees or groups are form to attend to the mending of broken fences and directing livestock to the grazing camps.

Table 7. Logistics regression showing years of farm experience and perception of price fixing as a constraint

\begin{tabular}{cccccccc}
\hline \multicolumn{7}{c}{ Variables in the Equation: } \\
\hline & & B & S.E. & Wald & df & Sig. & $\operatorname{Exp(B)}$ \\
\hline Step 1 ${ }^{\text {a }}$ & Fexp & & & 3.288 & 2 & .193 & \\
& fexp(1) & -1.099 & 1.307 & .707 & 1 & .401 & .333 \\
& fexp(2) & .693 & .833 & .693 & 1 & .405 & 2.000 \\
& Constant & -1.386 & .791 & 3.075 & 1 & .080 & .250
\end{tabular}

a. Variable(s) entered on step 1: fexp=Years of farm experience.

However, results showed that farmers with higher farm experience ( $\geq 20$ years) are $0.5(1 / 2.00)$ times less likely to perceive labour as a constraint than farmers with than 10years farm experience (Table 5).

\subsubsection{Livestock Theft}

Livestock pilfering was identified as one of the constraints to beef cattle production in the study areas. Stock pilfering causes economic loss, misfortune and hardship to the farmers. It is also a social malaise as this may reduce the level of trust among community members. Initiatives like branding and ear tagging of livestock to ameliorate pilfering failed because speculators and individuals are allowed to purchase livestock at farm gate. In Ga-kibi, $50 \%$ (Figure 1) of the respondents asserted that pilfering of their stock constitute a setback in their farming business while in Norma, $(20 \%)$ and Mogalakwena $(30 \%)$ of the respondents interviewed agreed that stock pilfering poses a problem in their production and marketing. As an interim measure, farmers in the study areas agreed to the introduction of 'farmers watch' and the formation of 'security committee' to reduce the incidence of stock pilfering.

\section{Livestock theft:}


Table 6. Logistics regression showing years of farm experience and perception of price fixing as a constraint

\begin{tabular}{cccccccc}
\hline \multicolumn{7}{c}{ Variables in the Equation: } \\
\hline Step 1 a $^{\text {a }}$ & fexp & B & S.E. & Wald & df & Sig. & Exp(B) \\
& fexp(1) & 2.043 & 1.192 & 2.938 & 1 & .087 & 7.714 \\
& fexp(2) & 1.572 & 1.085 & 2.097 & 1 & .148 & 4.814 \\
& Constant & -2.197 & 1.054 & 4.345 & 1 & .037 & .111 \\
\multicolumn{7}{c}{ a. Variable(s) entered on step 1: fexp= Years of farm experience. } \\
\multicolumn{7}{c}{}
\end{tabular}

The pilfering perception were investigated and results revealed that farmers with higher farm experience do not perceive pilfering or theft as a constraints as much as farmers with less farm experience. The results showed that farmers with more farm experience (20 years) are $0.21(1 / 4.814)$ times more likely to perceive livestock theft as a constraint. While farmers with farm experience of 11-20 years were 0.13 times more likely to perceive livestock theft as a constraint.

\section{Farmers, Perception of Beef Cattle Production as an Income Generating Source}

In South Africa, livestock account for $45 \%$ of the national agricultural domestic product. In Limpopo province, beef cattle constitute $17.6 \%$ of farming operation (Stats SA, 2002). Beef cattle have a lot of potential for development and income generation in the study area. The variables used in determining farmer's perception of beef cattle as income generating source were: main source of income, auxiliary source of income and minor source of income. In Ga-kibi, 55\% (Figure 2) of the respondents interviewed asserted that beef cattle production was their main source of livelihood. In Norma, $19 \%$ of the respondents depend on beef cattle production as an income generating source while in Mogalakwena, $26 \%$ depends on beef cattle as their main source of income. However, off-farm activities in the three study areas were not too pronounced as some of the farmers are either retiree or are involved in small stock production like goats and sheep. Livestock farming therefore, is a major source of income in the area.

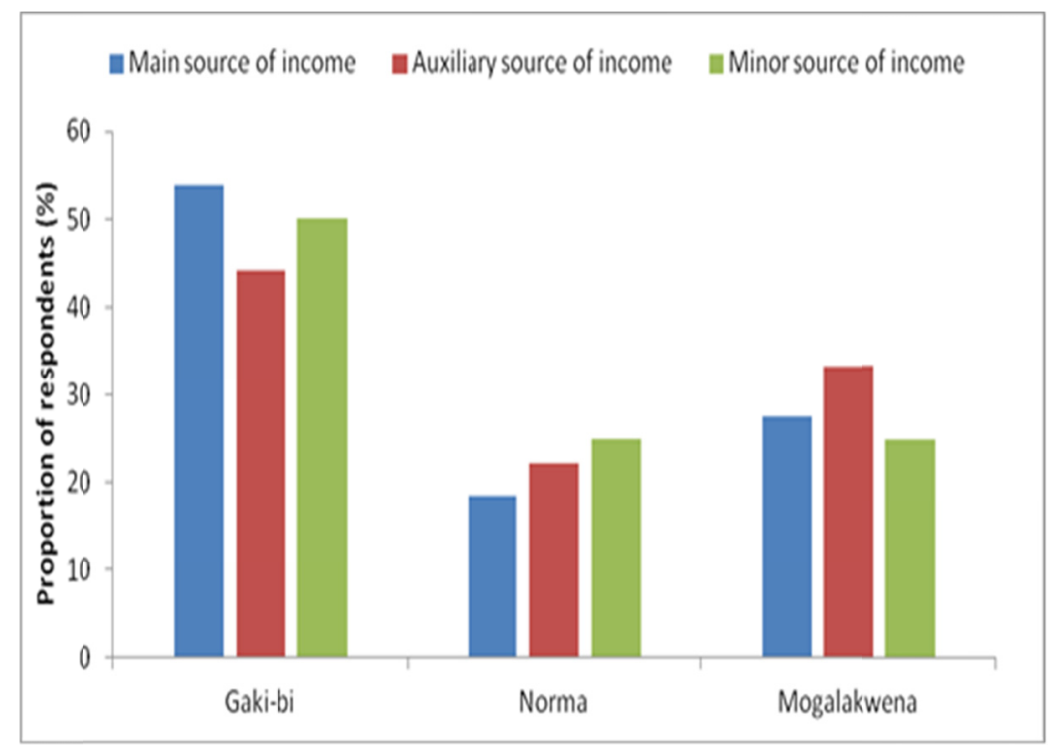

Figure 2. Farmers, perception of beef cattle production as an income generating source

\section{Speculators and Marketing in Ga-kibi, Norma and Mogalakwena}

Although other variables were identified as constraints, price fixing by speculators who are 'branded traders' were tagged by majority of respondents as a key limiting factor in beef cattle production and marketing in the three areas (Figure 2). Market speculators have access to infrastructures that allow them to purchase beef cattle from farmers at low prices and resale usually at a higher price. The four speculators interviewed asserted that prices are determined by the forces of demand and supply with abattoirs and feedlots staff monitoring the pace. 
These prices that are considered ideal are accepted as the prevailing price for the week. However, the approach to the price fixing is not usually clear to the beef cooperative farmers hence they consider the speculator as falsehearted. South Africa Agricultural Research for Development (SA ARD, 2006) noted that this form of marketing outlet is dominant in many rural areas of BLM and it is considered as one-sided method of steering business. However, as unsuitable as this marketing channel may be, it has its own benefits, for instance farmers do not incur marketing costs (cost of sales) because sale tariff or commission is not charged as sale take place at farm gate or their homestead without cost of transporting the beef cattle.

Nevertheless, the assertion of the speculators was that they also incur some feeding cost in the feedlots and abattoir before slaughter. Costs are predetermined before prices are fixed and usually the beef cooperatives farmers lack idea on value adding techniques which entails feeding the beef cattle to improve the live weight, carcass weight, dressing percentage and meat quality which are potential aspects that are of interest to abattoirs, slaughter houses and consumers. It is important that the speculators continue to feed these beef cattle as off-feed before slaughter can affect their live weight. For instance, studies have exemplified that livestock generally loses approximately $1 \%$ to $3 \%$ of their live weight when kept off-feed for 24 hours prior to slaughter (Bider et al., 1997). The abattoirs usually do not finish the slaughtering of all purchased beef cattle in a day and therefore; continue feeding until it is slaughtered. Depriving beef cattle of feed prior to slaughter is likely to reduce carcass weight, and therefore, results in low returns especially when they are sold on dead-weight basis; and the magnitude of this lose increases with time off-feed. However, speculators sometimes take advantage of the peculiar social-economic misfortune of the farmers to obtain lower prices far below the market value of the beef cattle. For instance, the speculators agreed that prices of beef cattle are cheaper when most farmers are returning their children back to school. Farmers are constrained to sell below the marketing price and often they swop their small stock (goats and sheep) for farm implements like wheel barrows which are used for fetching water for their livestock and household. Farmers that need funds for funeral or other unforeseen contingencies may also sell their beef cattle below the prevailing market prices. Distress sales may also result from insufficient fodder to feed the beef cattle. Another teething problem is that most speculators are not ready to go to remote areas because of poor road network associated with rural areas and high crime rate since market transactions are done with cash. Nevertheless, the speculators remain to be hunted after to purchase these beef animals from the farmers.

\subsection{Improving the Performance of Beef Cooperatives in the Study Area}

Enhancing the functioning of beef cooperatives requires farmers training and mentorship. Beef cooperatives farmers were not amply informed of the grading modalities and subsequent price fixing for livestock; it is therefore, imperative to include the farmers in the participatory process. The quest for auctioning are desirable but the modalities should be made clear to the livestock farmers. The addition of the smallholder farmers in the value chain administration is essential for the survival of rural agricultural cooperatives and marketing. Beef cooperatives farmers must form strategic partnership with the National Emergent Red Meat Producers' Organisation (NERPO) whose mandate amongst other things aims to develop the agricultural sector and ensure the right involvement of smallholder farmers within the ambit of agribusiness sector for long term sustainability. The beef cooperatives farmers must be encouraged to liaise with the Comprehensive Agricultural Support Programme (CASP) which has hitherto been assigned the responsibilities of infrastructural development for smallholder farmers in South Africa. Government must be consistent in offering technical assistance in areas like pest and diseases control, water resources management, market infrastructures and access, grading and stock pilfering. Service delivery must be fast tracked to indigent farmers.

\section{Conclusion}

The agitation for more investment in smallholder agriculture and farmers cooperatives has been gathering momentum and support and has been recognised as an avenue for poverty alleviation. However, there has been debate about its effectiveness since most smallholder farmers have no adequate access to the market as exemplified in this study. The results of the study reveal that beef cooperative farmers in Ga-kibi, Norma and Mogalakwena are saddled with the problem of pest and disease, water stress, market infrastructures, inadequate market access, unfair practices of price determination by speculators and stock pilfering. Beef cattle enterprise has a lot of prospect for development and income generation in the study area. Majority of the respondents depends on the beef cattle farming as an income source and as a means of livelihood. However, the daunting task of farmers embracing the principles and practice of cooperatives still persist in the study area. The study exemplified inadequate understanding of the purpose of cooperative, their obligations and rights, and how to manage the cooperative business in the area. Cooperatives' inability to provide transport services, inadequate commitment and lack of understanding of members' roles were causative factors. The solution to poverty reduction requires involving a greater part of the rural poor in agricultural cooperative activities that will 
enhance sufficient income. However, several factors have hindered the performance of smallholder cooperatives in developing countries.

\section{Acknowledgement}

The author gratefully acknowledge the International Centre for Development Oriented Research in Agriculture (ICRA), Limpopo Department of Agriculture (LDA), Blouberg Local Municipality (BLM), University of Fort Hare, University of Limpopo, University of Venda and Agricultural Research Council (ARC) for funding the fieldwork that culminated in the data collected for this paper. I also wish to acknowledge the contribution made by Mr. Odeyemi, A.S of the statistics department of the University of Fort Hare. My sincere acknowledgement to the three tribal communities Ga-kibi, Norma and Mogalakwena and the Agricultural Research for Development (ARD) team 2012, of which the author is a member for their invaluable contributions.

\section{References}

Bider, B., Ellis, M., \& Mckeith, F., (1997). Illini Pork Net. On line resources for the Pork Industry. University of Illini.

Bienabe, E., Coronel, C., LeCoq, J., \& Liagre., (2004). Linking Farmers to Markets: Lessons Learned from literature review of selected projects. Study Report. Final draft March 2004.

Department of Agriculture, Forestry and Fishery (2011). A Profile of the South African Beef Market value chain.

Kherallah, M., \& Kirsten, J. F. (2002). The New Institutional Economics: Applications for Agricultural Policy Research in Developing Countries. Agrekon, 41(2).

Machethe, C. L. (1990). Factors Contributing to poor performance of Agricultural Co-Operatives in less developed areas. Agricultural Economics Research, Policy and Practice in Southern Africa, 29(4).

Makhura, M., \& Mokoena, M., (2003). Market access for small-scale farmers in South Africa. In L. Nieuwoudt, \& J. Groenewald (Eds.), The Challenges of Change: Agriculture, Land and the South African Economy. Natal, South Africa: University of Natal Press.

Philip, K. (2003). Cooperatives in South Africa: Their Role in Job Creation and Poverty Reduction. Retrieved December 12, 2013 from http://www.sarpn.org.za/documents/d0000786/P872

S.A. ARD Team. (2006). Livelihoods in the rural areas of Blouberg Municipality (Gemarke and Early dawn Villages). Limpopo Province, South Africa.

StatSA. (2002). Statistics, South Africa

StatSA. (2007). Statistics, South Africa

Tukuta, M. (2011). Evaluation of impact of cooperatives on poverty alleviation among urban poor in Zimbabwe. $\mathrm{Ph} . \mathrm{D}$ thesis (Development studies) University of fort Hare.

Van der Walt, L. (2005). Resuscitation of the Cooperative Sector in South Africa. Paper presented at the International Cooperative Alliance XXI International Cooperative Research Conference, 11-14 August 2005, Cork, Ireland.

van Tilburg, A., \& van Schalkwyk, H. D. (2012). Strategies to improve smallholders' market access. In Unlocking markets to smallholders (pp. 35-58). Wageningen Academic Publishers.

Zwane, M. (2006). Background on the Capricorn District Municipality. Presentation at theIntroductory meeting. 10th April, 2006. 
Appendix 1: Map of the study area

\section{Study areas in Blouberg Local Municipality}

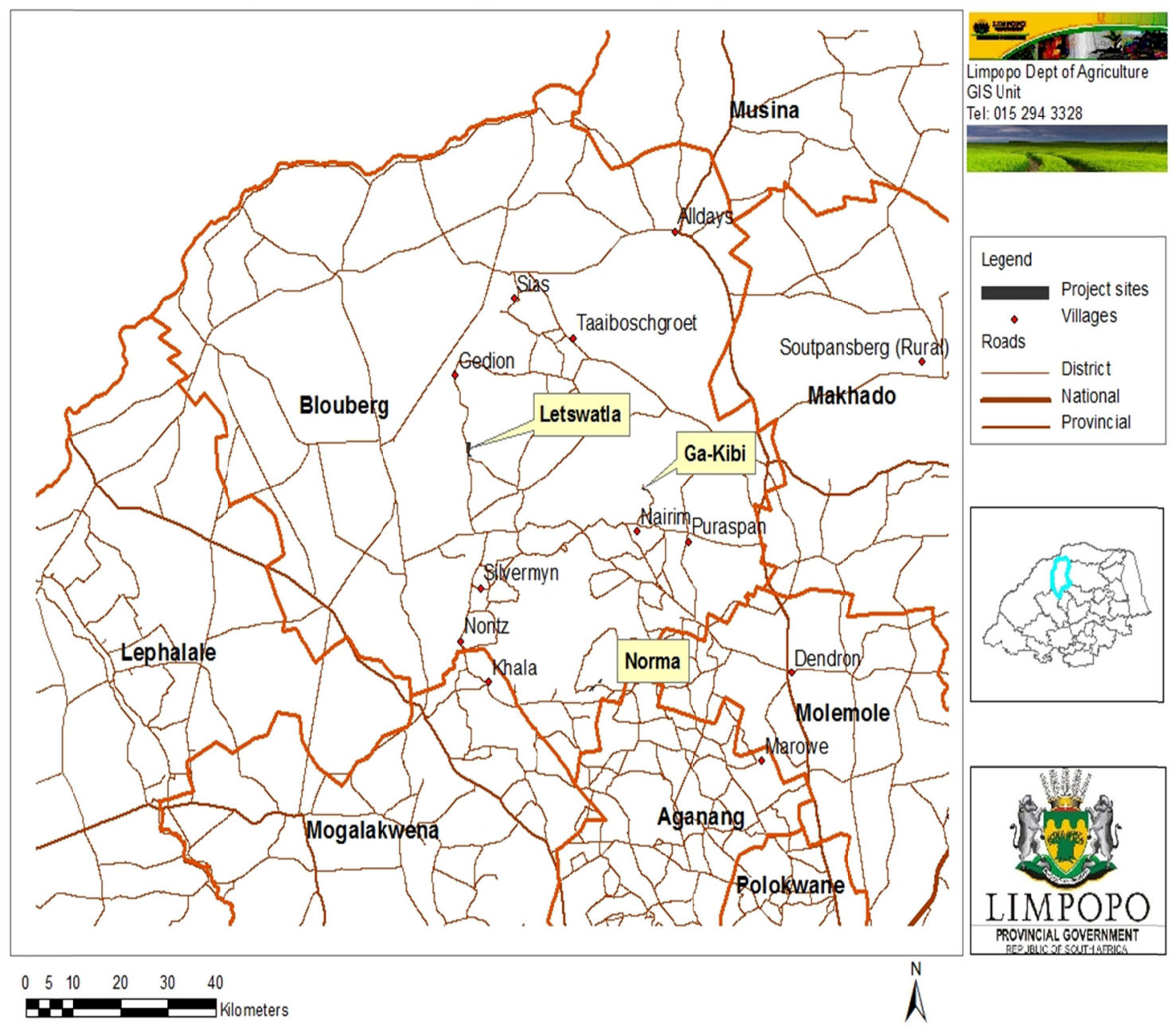

NatSOURCE: Limpopo Depment of Agricultureional ETD Portal;

S National ETD Portal;

South African theses and dissertations;

National ETD.

\section{Copyrights}

Copyright for this article is retained by the author(s), with first publication rights granted to the journal.

This is an open-access article distributed under the terms and conditions of the Creative Commons Attribution license (http://creativecommons.org/licenses/by/3.0/). 